\title{
Understanding Experiences of Sexuality with Cerebral Palsy through Sexual Script Theory
}

\author{
Tinashe M Dune $\mathrm{e}^{1,2}$ \\ ${ }^{1}$ Collaborative Research Network for Mental Health and Wellbeing, University of New England, Armidale, \\ Australia \\ ${ }^{2}$ Australian ICF Disability and Rehabilitation Research Program, University of Sydney, Sydney, Australia \\ Correspondence: Tinashe M Dune, Collaborative Research Network for Mental Health and Wellbeing, \\ University of New England, Armidale, Australia. Tel: 61-2-6773-3848. E-mail: tdune@une.edu.au
}

Received: October 9, 2012 Accepted: October 23, 2012 Available online: November 9, 2012

doi:10.11114/ijsss.v1i1.6

URL: http://dx.doi.org/10.11114/ijsss.v1i1.6

\begin{abstract}
This study explored how people with cerebral palsy (CP) negotiated and perceived their sexual interactions with others. In doing so, this research discusses participant conceptualizations of sexuality with CP. In-depth, semi-structured interviews were conducted with two women and five men with moderate to severe cerebral palsy from Canada and Australia. The interview discourse focused on how, if at all, interactional constructions of sexuality influenced the way in which participants expressed and negotiated their sexuality. Interview data were thematically analyzed using NVivo and manual line-by-line analysis. Negotiated sexuality with partners, and communication styles influenced understandings of sexuality with CP. Partner validation was important to participant understanding sexuality as was the style and quality of communication about sexuality between sexual partners. Sexuality was meaningful with a sense of closeness, experiences of affection and reciprocity. Personal sexual agency enabled negotiation of preferred sexuality as did perceived levels of socio-sexual compatibility. The findings confirm that sexuality is socially negotiated. For people with CP personal agency yields more satisfying socio-sexual outcomes. In this regard, the ability to make (and exercise) choice when negotiating interactional sexual experiences reinforces conceptualizations of oneself as a sexual being and sexual equal.
\end{abstract}

Keywords: cerebral palsy, sexual script theory, sexuality, disability, Australia, Canada, sexual agency

\section{Introduction}

As per Simon and Gagnon (1986, 1987, 2003) interactional constructions of sexuality are influenced and reinforced by public attitudes and interpretations. As such, people may be encouraged to engage in sexual activity only with those who are publically prescribed as appropriate (Simon \& Gagnon, 1986). The public construction of who is an appropriate sexual partner often excludes individuals with disabilities and their experiences of sexuality (Guildin, 2000). If people with disabilities are publically (i.e., mass media) excluded from portrayals of sexuality they may not being considered as viable sexual partners and thus experience reduced sexual opportunities (Overstreet, 2008). Research indicates that exclusionary constructions of sexuality and disability have a negative impact on how people with cerebral palsy experience their sexuality (see Wazakili, Mpofu \& Devlieger, 2009; Xenakis \& Goldberg, 2010; Rurangirwaa, Van Naarden Braun, Schendel \& Yeargin-Allsopp, 2006). For instance, Lawlor et al.’s (2006) qualitative research on families of children with cerebral palsy indicated that "reported barriers to participation were the attitudes of individuals and the ingrained attitudes of institutions...The attitudes of strangers towards the child and family which altered the choice of activity for some families” (p. 225). As such, sexual participation and negotiation is mediated by public and interactional sexual scripts which may discourage sexual behaviour with people with a disability.

People with disabilities and typical others may internalize sexual scripts which do not account for variance in the human condition. Without a framework which allows people with impairment to express their thoughts, feelings and desires their socio-sexual experience(s) may not be acknowledged (Blakar \& Nafstad, 2006; Gould, 2009; Faulkman et al., 2005; McCormack et al., 2010). Due to pervasiveness of interactional (sexual) scripts which exclude people with cerebral palsy (or other disabilities) understanding the salience of these scripts is of interest. This research builds on understandings of interactional sexual scripts by allowing people with cerebral palsy to 
describe the influence (if at all) of sexual scripts on their constructions of their sexuality.

\section{Methods}

This paper presents an excerpt of results from a doctoral project which used a hermeneutic phenomenological approach to explore the salience of sexual scripts (public, interactional and private) in constructions of sexuality by people with Cerebral Palsy. In-depth interviews were conducted with duration of one to two and a half hours. A semi-structured interview guide was used for data collection and comprised of the following sections: demographics and severity of disability, private sexual scripts, interactional sexual scripts, public sexual scripts and reflective summary. Interviews were conducted via email, telephone and/or face-to-face (based on participant preference).

In the interactional sexual scripts section of the interview participants were asked questions to ascertain if any interactional constructions of sexuality influenced the way in which they expressed and negotiated their sexuality. Questions about sexual relations were included in order to identify how people with Cerebral Palsy describe and measure mutually satisfying sexual activity. For example, "Please explain your romantic and/or sexual history" and "What would you consider the most important sexual transitions in your life?" were intended to allow participants to express their experiences with sexuality. The question "Can you describe to me the best sexual experience(s) you have had?" and "In your opinion, what makes 'good' sex good” were used to ascertain how participants conceptualized sexual experiences. Through the data collected the researcher aimed to identify instances in which interactional sexual schemas affected how participants experienced and conceptualized their sexual relationships, intimacy and sexual desires.

The data were analyzed for content by identifying topics and substantive categories within participants' accounts in relation to the study's objectives. In addition, NVivo 9 was used to ascertain topical responses and emergent substantive categories, coding particularly for word repetition, direct and emotional statements and discourse markers including intensifiers, connectives and evaluative clauses. Due to the rich and contextual nature of the data, participant's responses have been presented in their conceptual entirety.

\section{Participant Recruitment}

This study included seven participants; five men and two women. Four of the participants were from Australia and three from Canada (see Table 1). The study recruited from Canada and Australia in order to enhance the possibility of finding members of the target population to participate.

In Australia, participants were recruited through advertisements published in community newspapers, bulletins, through advocacy group and sexuality and/or disability focused newsletters and webpages. In addition, the snowballing technique was carried out at the end of participant interviews and required asking each participant if they knew someone who met the eligibility criteria and, if so, whether s/he would be willing to give that person a copy of the participant information sheet. The author did not know the identity of this person, and the interviewee did not know if that person agreed to participate in the project or not.

In Canada, participants were sought through the Attendant Care Program in Ottawa, Ontario, Canada. The Attendant Care Program services two of the major educational institutions in the city with round-the-clock provision of personal care for tertiary students with disabilities who live in the university residence buildings. The program which has been running for over 20 years services approximately 50 - 60 students per year with numbers increasing every year. Due to the client-directed style of the program clients are provided with the resources they need to live independently through the provision of dignity-focused care and accessible living arrangements. As the author was formerly employed by the service she forwarded the coordinator of the program the details of this project and was informally given permission to ask clients (the majority of whom had Cerebral Palsy) of the Attendant Care Program if they would like to participate. 
Table 1. Participant Summary

\begin{tabular}{|c|c|c|c|c|c|c|c|}
\hline $\begin{array}{l}\text { Participant } \\
\text { (Pseudonym) }\end{array}$ & Sex & $\begin{array}{l}\text { Type of } \\
\text { Cerebral } \\
\text { Palsy }\end{array}$ & $\begin{array}{l}\text { Assistive } \\
\text { Devices or } \\
\text { Services }\end{array}$ & $\begin{array}{l}\text { Socio-economic } \\
\text { Status, } \\
\text { education and } \\
\text { ethnicity }\end{array}$ & $\begin{array}{l}\text { Medical } \\
\text { Interventions }\end{array}$ & $\begin{array}{l}\text { Living } \\
\text { Arrangements }\end{array}$ & Sexual Profile \\
\hline John & Male & $\begin{array}{l}\text { Spastic } \\
\text { Quadriplegic } \\
\text { Cerebral } \\
\text { Palsy } \\
\text { (severe) }\end{array}$ & $\begin{array}{l}\text { Mechanized } \\
\text { wheelchair, } \\
\text { daily } \\
\text { personal } \\
\text { assistance } \\
\text { from others }\end{array}$ & $\begin{array}{l}\text { Upper-middle } \\
\text { class, tertiary } \\
\text { education, } \\
\text { Caucasian } \\
\text { Australian }\end{array}$ & $\begin{array}{l}\text { Major } \\
\text { musculoskeletal } \\
\text { surgery during } \\
\text { childhood and } \\
\text { adolescence. } \\
\text { Rehabilitative } \\
\text { maintenance. }\end{array}$ & $\begin{array}{l}\text { Lived with his } \\
\text { mother in his } \\
\text { family's home }\end{array}$ & $\begin{array}{l}\text { Heterosexual, } \\
\text { sexually active, } \\
\text { no history of } \\
\text { long term } \\
\text { sexually } \\
\text { intimate } \\
\text { relationships }\end{array}$ \\
\hline Mary & Female & $\begin{array}{l}\text { Spastic } \\
\text { Paraplegic } \\
\text { Cerebral } \\
\text { Palsy } \\
\text { (moderate) }\end{array}$ & $\begin{array}{l}\text { Occasional } \\
\text { use of } \\
\text { crutches }\end{array}$ & $\begin{array}{l}\text { Middle class, } \\
\text { tertiary } \\
\text { education, } \\
\text { Caucasian } \\
\text { Australian }\end{array}$ & $\begin{array}{l}\text { Major } \\
\text { musculoskeletal } \\
\text { surgery during } \\
\text { childhood and } \\
\text { adolescence. } \\
\text { Rehabilitative } \\
\text { maintenance. }\end{array}$ & $\begin{array}{l}\text { Lived } \\
\text { independently } \\
\text { in an apartment } \\
\text { with her partner }\end{array}$ & $\begin{array}{l}\text { Heterosexual, } \\
\text { in a long term } \\
\text { sexual } \\
\text { relationship at } \\
\text { time of } \\
\text { interview }\end{array}$ \\
\hline Brian & Male & $\begin{array}{l}\text { Ataxic } \\
\text { Quadriplegic } \\
\text { Cerebral } \\
\text { Palsy } \\
\text { (severe) }\end{array}$ & $\begin{array}{l}\text { Mechanized } \\
\text { wheelchair, } \\
\text { daily } \\
\text { personal } \\
\text { assistance } \\
\text { from others }\end{array}$ & $\begin{array}{l}\text { Middle class, } \\
\text { tertiary } \\
\text { education, } \\
\text { Caucasian } \\
\text { Australian }\end{array}$ & $\begin{array}{l}\text { Major } \\
\text { musculoskeletal } \\
\text { surgery during } \\
\text { childhood and } \\
\text { adolescence. } \\
\text { Rehabilitative } \\
\text { maintenance. }\end{array}$ & $\begin{array}{l}\text { Lived in an } \\
\text { independent } \\
\text { living facility }\end{array}$ & $\begin{array}{l}\text { Heterosexual, } \\
\text { sexually active, } \\
\text { no history of } \\
\text { long term } \\
\text { sexually } \\
\text { intimate } \\
\text { relationships }\end{array}$ \\
\hline Leah & Female & $\begin{array}{l}\text { Spastic } \\
\text { Paraplegic } \\
\text { Cerebral } \\
\text { Palsy } \\
\text { (moderate) }\end{array}$ & $\begin{array}{l}\text { Mechanized } \\
\text { wheelchair, } \\
\text { daily } \\
\text { personal } \\
\text { assistance } \\
\text { from others }\end{array}$ & $\begin{array}{l}\text { Lower-middle } \\
\text { class, tertiary } \\
\text { education, } \\
\text { Caucasian } \\
\text { Australian }\end{array}$ & $\begin{array}{l}\text { Major } \\
\text { musculoskeletal } \\
\text { surgery during } \\
\text { childhood and } \\
\text { adolescence. } \\
\text { Rehabilitative } \\
\text { maintenance. }\end{array}$ & $\begin{array}{l}\text { Lived in an } \\
\text { apartment with } \\
\text { her boyfriend. }\end{array}$ & $\begin{array}{l}\text { Heterosexual, } \\
\text { in a long term } \\
\text { sexual } \\
\text { relationship at } \\
\text { time of } \\
\text { interview }\end{array}$ \\
\hline Ian & Male & $\begin{array}{l}\text { Ataxic } \\
\text { Quadriplegic } \\
\text { Cerebral } \\
\text { Palsy } \\
\text { (severe) }\end{array}$ & $\begin{array}{l}\text { Mechanized } \\
\text { wheelchair, } \\
\text { daily } \\
\text { personal } \\
\text { assistance } \\
\text { from others }\end{array}$ & $\begin{array}{l}\text { Lower-middle } \\
\text { class, tertiary } \\
\text { education, } \\
\text { Caucasian } \\
\text { Canadian }\end{array}$ & $\begin{array}{l}\text { Major } \\
\text { musculoskeletal } \\
\text { surgery during } \\
\text { childhood and } \\
\text { adolescence. } \\
\text { Rehabilitative } \\
\text { maintenance. }\end{array}$ & $\begin{array}{l}\text { Lived in an } \\
\text { independent } \\
\text { living facility. }\end{array}$ & $\begin{array}{l}\text { Heterosexual, } \\
\text { sexually active, } \\
\text { no history of } \\
\text { long term } \\
\text { sexually } \\
\text { intimate } \\
\text { relationships }\end{array}$ \\
\hline Trevor & Male & $\begin{array}{l}\text { Spastic } \\
\text { Quadriplegic } \\
\text { Cerebral } \\
\text { Palsy } \\
\text { (severe) }\end{array}$ & $\begin{array}{l}\text { Mechanized } \\
\text { wheelchair, } \\
\text { daily } \\
\text { personal } \\
\text { assistance } \\
\text { from others }\end{array}$ & $\begin{array}{l}\text { Upper-middle } \\
\text { class, tertiary } \\
\text { education, } \\
\text { Caucasian } \\
\text { Canadian }\end{array}$ & $\begin{array}{l}\text { Major } \\
\text { musculoskeletal } \\
\text { surgery during } \\
\text { childhood and } \\
\text { adolescence. } \\
\text { Rehabilitative } \\
\text { maintenance. }\end{array}$ & $\begin{array}{l}\text { Lived in an } \\
\text { independent } \\
\text { living facility }\end{array}$ & $\begin{array}{l}\text { Heterosexual, } \\
\text { in a long term } \\
\text { sexually } \\
\text { intimate } \\
\text { relationship at } \\
\text { time of the } \\
\text { interview }\end{array}$ \\
\hline Alex & Male & $\begin{array}{l}\text { Spastic } \\
\text { Quadriplegic } \\
\text { Cerebral } \\
\text { Palsy } \\
\text { (severe) }\end{array}$ & $\begin{array}{l}\text { Mechanized } \\
\text { wheelchair, } \\
\text { daily } \\
\text { personal } \\
\text { assistance } \\
\text { from others }\end{array}$ & $\begin{array}{l}\text { Upper-middle } \\
\text { class, tertiary } \\
\text { education, } \\
\text { Caucasian } \\
\text { Canadian }\end{array}$ & $\begin{array}{l}\text { Major } \\
\text { musculoskeletal } \\
\text { surgery during } \\
\text { childhood and } \\
\text { adolescence. } \\
\text { Rehabilitative } \\
\text { maintenance. }\end{array}$ & $\begin{array}{l}\text { Lived in an } \\
\text { independent } \\
\text { living facility }\end{array}$ & $\begin{array}{l}\text { Homosexual, } \\
\text { high frequency } \\
\text { of casual } \\
\text { sexual } \\
\text { encounters, no } \\
\text { history of long } \\
\text { term sexually } \\
\text { intimate } \\
\text { relationships }\end{array}$ \\
\hline
\end{tabular}

\section{Results and Discussion}

Five sub-themes characterized the perceived influence of others on sexuality: Peer Acceptance of Impairment and Disability, Feeling Worthy of Sexual Experiences with Others, The Importance of Communication, The Role of Sexual Intimacy and The Importance of Socio-Sexual Compatibility. 


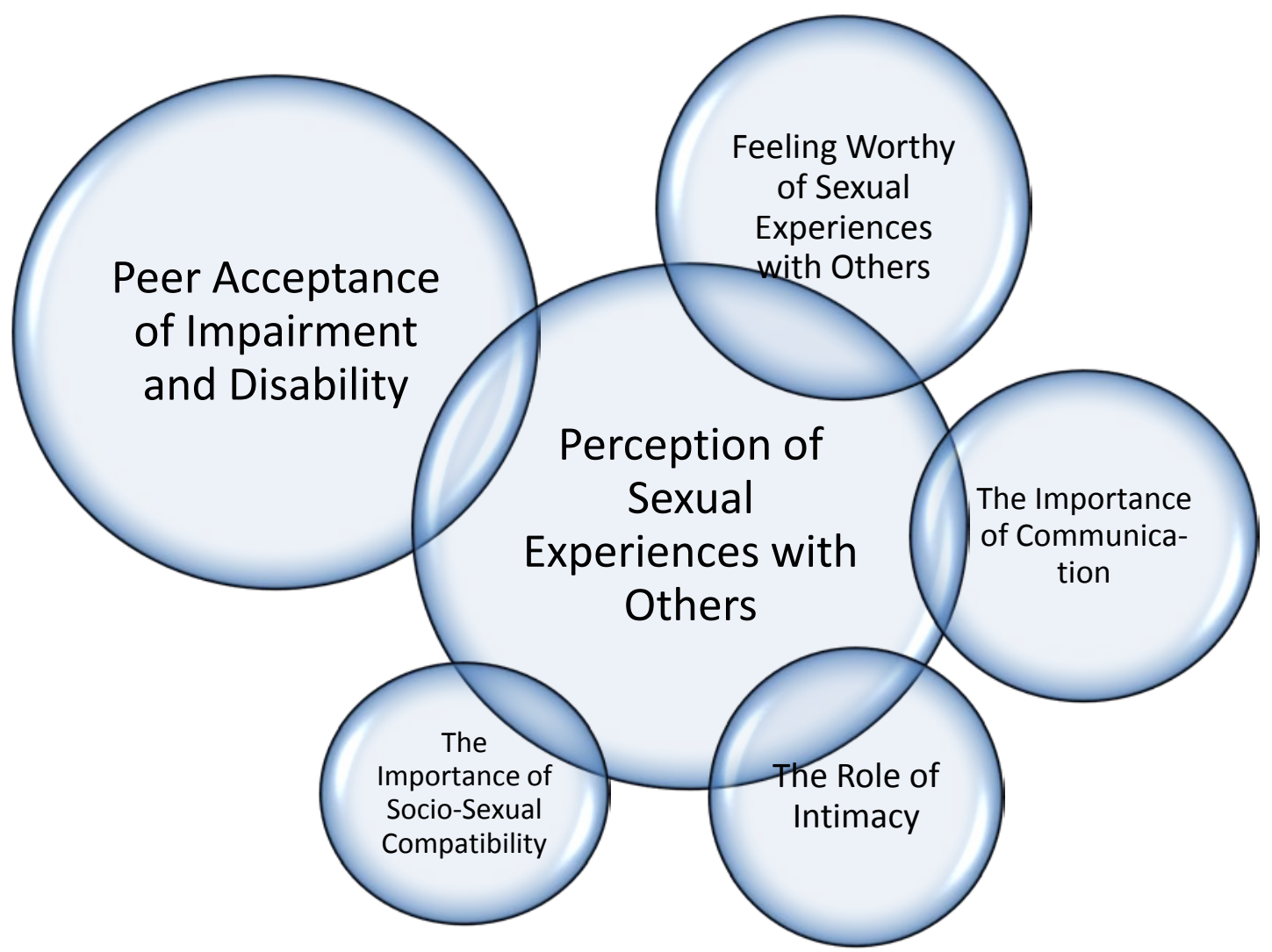

Figure 1. Perception of Sexual Experiences with Others Theme and Sub-themes (Note: The size of the spheres is a visual representation of the relative salience of sub-themes within the theme)

\subsection{Peer Acceptance of Impairment and Disability}

Peer acceptance of impairment and/or disability was a significant influence on participants. Informants articulated three concepts associated with peer acceptance of impairment and/or disability: 1) acceptance based on understanding of impairment and disability (Wu \& Mok, 2006), 2) acceptance as an unusual trait (Howland \& Rintala, 2001) and, 3) tolerating difference (Milligan \& Neufeldt, 2001). For instance, Alex articulated highlighted the importance of being with an individual who was accepting of impairment and disability:

Alex: My ideal partner would be extremely open-minded. It would be helpful if they have had some experience with the disabled community, but I realize how rare that is. I tend to think that I would date someone older only because they have more life experience. My lack of physical ability means that I am relying on my partner to accept that they need to facilitate much of the movement.

Trevor also indicated that finding a partner who understood and could accept someone with severe physical impairment. He observed:

Trevor: My care needs do influence my sexuality. I think this is a result of how much physical assistance I require. It tends to make my sexual partners very apprehensive and unsure of how to handle the situation. I need help with all of my daily functioning, and it is not often that I found someone who is truly comfortable with my level of disability. So, yes, my disability does influence my sexuality.

While informants indicated that they would like to be with someone who understood and accepted impairment and disability they also articulated that it was a rare. Brian explained:

Brian: The one couple that I know. It seems odd. I can’t imagine how they dealt with it. One thing I can tell is that the wife [physically and mentally typical] is one of the most serene and unflappable people I have ever met. And that may be at the heart of it. And they also had a very successful, very well-balanced kid. I often wonder, at the core, about her [the wife's] emotional stability.

Participants also considered acceptance of impairment and disability an unusual character trait or improbable in others. For instance, Ian discussed how potential sexual opportunities would transpire with an individual who 
had no prior experience with disability.

Ian: It takes someone with an unusual character, I mean an unusual gal to come up and speak to someone [with a disability]. I mean if you're talking about someone who's had no experience with disability and you think what are they going to do are they necessarily going to come up and say "hello" or strike a conversation for absolutely no reason at all or are they not. It would take an unusual girl indeed.

Furthermore, John explained that acceptance from one's peers is not simply a matter of accepting atypical sexual circumstances but accepting the realities of severe physical disability. He observed:

John: In my mind they'd have to be accepting of some very faulty equipment. And this isn't the sexual, it's a lot of medical needs, I'm all those things. I know of one fellow who has obviously deliberately married a woman [with a disability] and he must have known that she had polio. I mean he must have known, I mean you don't just get polio, and I know she had polio earlier in her life. And you know it was rather difficult for her, so look, I mean, I don't know how they came to their arrangements or understandings.

John has emphasized the idea that for people with severe physical disabilities it may be difficult to interactionally negotiate the terms of engagement as he perceived others to be unaccepting and intolerant.

All the male participants felt that someone who would accept issues related to impairment and disability was rare and with considerable emotional resources. Similarly, the female informants, both of whom were in steady long term relationships, expressed that they too were sceptical of finding such an individual. For instance, Mary observed that while her boyfriend was accepting of impairment and disability others in his extended circle would not be:

Mary: Yes, he [her boyfriend] does accept me and my disability and that's a nice thing. Especially when I do think sometimes that there are people in his extended circle who would probably say, you know, "What does he see in her?”

The view that prospective or actual partners could be influenced by social networks supports the salience of interactional schema. Although, Leah also alluded to the idea that others were generally unaccepting of impairment and disability she acknowledged incidences in which she met someone who was tolerant:

Leah: Sometimes you meet great people. I've been so surprised, which is nice to be, when you realize how jaded you are when you meet someone who's great and doesn't give a shit and you're thinking in your head all kinds of things and you think, "hang on a minute. I'm pretty awesome."

Interactional experiences of intolerance from others were perceived to influence socio-sexual development and one's construction of their sexuality. For instance, Mary explained:

Mary: For all their good attributes, kids are naturally mean. By the time I started secondary school I was just pretty nervous and I ended up with a problem with the school structure. A large group of girls who were friends from the junior school managed to come through into the same Year 7 class, when they should have been broken up. So, for whatever reason, they chose me as the person they were going to make fun of. Yeah, I don't think my social skills were brilliant earlier in school because I was so uncomfortable.

Mary's experiences of social ostracism and exclusion due to peer intolerance in elementary and high school may not have been directly linked to her sexuality. However, experiences of intolerance in youth may impede socio-sexual development (Wiegerink, Roebroek, Donkervoort, Stam, \& Cohen-Kettenis, 2006). Ian and Alex acknowledged experiences of intolerance from others that influenced their construction of sex.

Ian: Since my first sexual experience, I have become much more jaded about sex.

Alex: I am kind of jaded when it comes to romance. In my experience, every time I have tried to enter into a romantic relationship - or every time I have had those feelings for a guy I have been rebuffed and hurt.

Experiences of intolerance from others as indicated by all the participants influenced their sense of sexual worthiness and the construction of themselves as potential sexual partners.

\subsection{Feeling Worthy of Sexual Experiences with Others}

Feelings of sexual worthiness (or the lack thereof) were significant to participants' constructions of their sexual worth. Sexual worthiness overlaps both interactional and private sexual schema. On the one hand, feeling worthy of sexual experiences with others is mediated by sexual experiences with others. On the other hand, feeling worthy of sexual experiences with others is consolidated through private processes. While this duality exists feelings of sexual worthiness are primarily dictated by one's socio-sexual experiences with others (Esmail et al., 2010). As such, informants describe feeling worthy of sexual experiences with others as a result of: 1) sexual 
validation from others (Esmail et al., 2010), 2) being sexually pleasured by one’s partner (Howland \& Rintala, 2001), 3) pleasuring one's partner (Taleporos \& McCabe, 2002) and 4) the impact of negative sexual experiences on perceptions of sexual worth (Esmail et al., 2010). Alex, for example, explained that feeling sexually worthy was the result of validation from sexual partners:

Alex: The best sex I ever had was with a popular television personality in the summer of 2008. I think it was mostly because I didn't have to try and convince him that I was worthy of him. He actively sought me out and that made the sex feel more authentic. It was passionate and wild - kind of like what you would see in the movies - or at least that's how I remember it. I also think the best sexual encounters are humorous ones. It makes it less "scripted" and natural.

John also noted that feeling worthy of sexual attention was out of the ordinary.

John: I mean again, I guess, the only reference point I'd have there is the rather sudden response of this former carer. I don't know, but under any other circumstances either one of us could have complained about being assaulted and neither of us did [LAUGHS].

In this respect John jokingly alluded to the idea the he was not worthy as a sexual candidate as the sexual activities that he and his former carer engaged in may have been construed as sexual abuse even though both parties unambiguously consented to the behaviour.

For Leah and Mary feeling worthy of sexual attention and sexual experiences with others was reinforced by their partners wanting to pleasure them and therefore taking the initiative to start sexual activity or reinforce intimacy.

Leah: I probably ... some of the best sex, I think, is probably when we've started mucking around doing something and neither one of us really wanted sex and for whatever reason we've ended up doing it but I think at the times I've probably talked about are the times when he's initiated it. Sometimes I feel a little bit pressured when I go to initiate it because I think, you know, oh we shouldn't do that now.

In addition, Trevor and Brian felt that their sexual worth was proven by pleasuring their partners. Their thoughts imply that doting on one's partner made them sexually worthy of their partners.

Trevor: I am an old-fashioned romantic and enjoy the art of dating. I thoroughly enjoy getting to take care of my partner, and treating them like the Queen of the world. I am the kind of guy who still believes that chivalry has its place.

Brian: Dinner and a spa with candles. Good wine. Good timing is important. Kissing, feeling their hair. Heading towards the breasts and caressing their breasts.

Based on responses from Trevor and Brian pleasing one's partner involves both physical and emotional pleasure through sexual activity, chivalry and, the creation of an intimate atmosphere. Leah however, was concerned that what she perceived as a lack of confidence stopped her from believing she could please her partner or initiate sexual activity.

Leah: Yeah, just having a bit more confidence. There are times where I worry that I haven’t pleased him and, you know, he's very reassuring. But yeah, I haven't been encouraged in any kind of physical pursuit let alone having sex with somebody.

Leah's partner was reassuring, but other participants explained that they had not had many (if any) experiences of reassurance or validation of their sexual worth from others. For example, Alex, John and Ian explained that negative sexual experiences with others have made them feel as though potential sexual partners would not see them as sexually worthy.

Alex: The first guy that I slept with told me that I was a "pity fuck.” This is an experience that has shaped my sense of sexual encounters ever since, because I often wonder if the majority of my encounters are on that premise.

John: In all honesty, I don’t feel as though I am sexually desirable. I think this stems from me, like my disability makes me an outsider.

Ian: With my first couple sexual encounters, I was much more naïve. I would think they would want to come back for more (I still do), and when they didn't I would become depressed because I would automatically relate it back to my disability. I still secretly hope they want to come back for more. They often don't.

Feelings of sexual unworthiness influenced participants' constructions of their own sexuality in that it reinforced negative perceptions of themselves. In order to alleviate or avoid the potential of negative sexual experiences with others participants indicated that communication was integral to fostering satisfactory sexual encounters 
and relationships.

\subsection{The Importance of Communication}

Communication was also of significant importance to how people with Cerebral Palsy experienced their sexuality. Respondents noted the importance of: 1) constructing a sexual dialogue to use with potential partners (Kralik \& Bostock, 2008), 2) communicating the role that disability and impairment play in intimate relationships (Kralik \& Bostock, 2008), 3) Communicating the impact of impairment and disability with potential sexual partners (Papile, 2009) and, 4) communication to reconstruct normative expectations of sexuality (Esmail, Esmail \& Munro, 2001). In terms of constructing an effective sexual dialogue Trevor, John and Brian, for instance, noted that being light-hearted, honest and open about their abilities was a staple of their sexual dialogue with potential partners.

Trevor: I feel that communication especially when situating disability and sexuality is important. I try to put [my partners] at ease through humor and honesty about my abilities.

Ian: Openness with my partner is the key in this regard. I cannot afford to be shy about my needs, as these are discussions that need to happen before physical intimacy.

Brian: For me, it's all about engaging with my partner to determine their comfort level as well as mine, and working to combine those two. There is no sense in hiding anything, because my physical needs are very apparent, so I have never openly denied MY [participant's emphasis] need for care.

John, too, felt that discussing the impact of disability on intimate relationships was important; however, he acknowledged that this dialogue was not only restricted to sexual activity but was necessary in order to make the dynamics of an intimate relationship with him clear to a potential partner.

John: Oh yes. Look in my view it would be unfair to present yourself to someone and not engage in these conversations that says "well look, I cannot guarantee that I can support you. But what I can say is that you may end up doing a lot of the work. And what I can say it that not only will you have to do all the work, but you may end up doing a lot of the house work, the child rearing work, you may end up doing a lot of everything." And look, under those circumstances I would expect $99 \%$ of people to be out the door so quickly.

Alex also iterated the importance of communicating the role that disability and impairment plays in intimate relationships. To Alex these discussions were indicative of a sexual script which influenced his construction of sexuality.

Alex: I've learned what it was "supposed" to be like. When you constantly have one-night stands with "randoms", a certain protocol is formed. I learned that sex follows certain scripts. Having a disability and having sex follows a very specific script. One key element of that script is to put my partner at ease regarding the disability during and before the sex.

Communicating the impact of impairment and disability seemed to be an important feature in what Alex described as a component of the "script of having a disability and having sex." Part of communicating the impact of impairment and disability on sexuality included encouraging the reconstruction of sexual expectations (Papile, 2009). This involved approaching sexual encounters without distinctive expectations or preconceptions and allowing communication to navigate the course of the encounter. For instance, Ian explained that communicating the impact of impairment with potential sexual partners was imperative to reconstructing sexual expectations in order to ensure satisfactory sexual encounters.

Ian: I also try to prepare my partners for how a sexual encounter with me would be different than with an able-bodied individual... It just means that a partner has to communicate and reconstruct what sex can be when they are with me.

Leah described some of what she and her partner did in order to reconstruct the expectation of normative sexual expectations during sexual encounters.

Leah: I mean we still try to do the normal stuff. But if my leg goes spastic I just go "hip, hip” whichever one it is. "Move it, move it, move it, no I can't go there!" It's not always painful, sometimes it is, but sometimes that helps so you just stay with the pain because you get a pay-out. There are a few positions we tried because they're meant to be easy on your hips but you don't get a lot from them.

Leah's experience of directing her partner through communication allowed the two of them to be flexible and open about what did and did not work for them as intimate partners. As such, participants indicated that communicating with sexual partners about disability and sexuality was a multidimensional process which involved honesty, openness and a receptive partner. In this way, communication fostered an atmosphere for 
satisfactory sexual encounters and intimacy.

\subsection{The Role of Sexual Intimacy}

Intimacy was described as integral to satisfactory sexual relationships. Participant data reveals intimacy as: 1) a sense of closeness and experiences of affection (Jemtå, Fugl-Meyer \& Öberg, 2008), 2) reciprocity and a sense of relationship satisfaction (McCabe, Cummins \& Deeks, 2000) and, 3) the result of friendship, respect and familiarity (Papile, 2009). These interactional experiences with sexual partners positively influenced constructions of individual sexuality. For instance, Mary provided an example of how intimacy, characterized by a sense of closeness and experiences of affection, influenced her relationship with her partner and her experiences of sexuality with him:

Mary: We like to light some candles because sometimes-I find when I'm wanting to relax you need that sensory deprivation, you've got to have the TV off and no music and I like to have nice light and quiet. So we'll put some candles on, sometimes we'll have a bath together. I just like sitting in the bath and talking in the bath. We don't always fool around one side or the other but sometimes we have a shower together, you know, wash each other's backs, that kind of thing. I like that kind of intimacy and that kind of intimacy is a big part of sexual attraction for me as well. Whereas I think sometimes guys have two very separate things - there's intimacy and then there is sex. I get that - I think. I mean given I didn't have sex until a couple of years ago, you don't get intimacy from anything else. You don't get that moment of —and for me because it's so physical, the moment where you're not thinking about anything else except doing something physical and it's just quite a connection to someone. And you know, when you don't do it [have sex] for a little bit it changes the dynamic and I think you get some harmony back from doing that [having sex]. I just like that connection.

For Mary, the process of fostering a sense of closeness and affection with her partner through physical activities was important to her construction of intimacy. These activities denote nurturance and love reinforced by the emotional and mental connection she has with her partner and the sense that she is accepted and loved. Brian also felt that a sense of closeness and affection via certain activities encouraged intimacy.

Brian: I think that foreplay is the key to good sex because it creates intimacy. Without intimacy on some level, I think you cannot have good or even satisfactory sex.

Intimacy, for Brian and Mary, was further emphasized by reciprocity and a sense of satisfaction with both their partners and sexual activities. Five of the participants also alluded to intimacy as important to positive constructions of their sexuality. John's experience with a former carer of many years highlighted that intimacy is an iterative process which involved friendship, respect, affection and familiarity.

John: I was somewhat aware that I might not have had first claim on her, let's put it that way. So when I realized that "oh she’s actually kissing me” my response what "oh yes I'm going to encourage this". So I mean I remember quite deliberately putting my arms around her waist and locking them in a sense that "you're not going to go anywhere for sometime" and then it came to the point of kissing her and holding her for as long as humanly possible and she seemed quite happy to play along as well. So we were both very much involved. And I mean for me it's probably the first and the last time that I've been involved so intimately in probably 10 years and probably a bit more. I mean look, we honestly didn't negotiate it, I mean, I just kinda happened. It was after she dressed me and bathed me and she was almost ready to go. And as far as I remember she came over to say goodbye and I was not aware and was not necessarily planning for anything to happen. To be absolutely frank, I don't remember how it happened. I remember where I was sitting, I remember that suddenly she was sitting on my lap. I mean I don't even remember us necessarily looking at each other and saying anything. I guess it was quite, I think, quite comfortable for me, and quite easy for me. Obviously I mean I don't know how we would have negotiated it. I don't know if it was something that she had planned to do and she was just going to see what I did in response. I can't say whether she was the initiator just certainly that I was aware she was sitting on my lap and then we started kissing and I mean, well I knew then I had a choice so I decided to make it very clear, I put my arms around her and we continued. And look nothing was said but it was quite clear that both of us were quite happy to let it happen.

For John the long standing relationship he had with his former carer fostered friendship, respect, affection and familiarity due to the intimate nature of their relationship. In doing so, both John and his former carer felt comfortable crossing the parameters of friendship and share a highly sexualized moment with one another. It can be seen that feeling comfortable with one's partner facilitates an interactional atmosphere in which participants can engage in mutually satisfying experiences of sexuality. In this regard, an ideal sexual partner could be identified in an individual who was socially and sexually compatible. 


\subsection{The Importance of Socio-Sexual Compatibility}

Three participants indicated that socio-sexual compatibility was of least importance to how they perceived their sexual experiences with others. In contrast, another three participants described instances in which socio-sexual compatibility supported their constructions of satisfying sexual relationships. In particular, participant data highlighted: 1) the role that socio-sexual compatibility plays in intimate relationships, 2) socio-sexual compatibility as a conglomerate of awareness, receptiveness and attentiveness to one's partner and their socio-sexual needs (Phillips, 2008) and, 3) perceived emotional, mental, social and physical compatibility (Dune \& Shuttleworth, 2009). Mary's experiences with her boyfriend exemplify the role that socio-sexual compatibility played in her relationship.

Mary: And I think we're very real with each other. We talk about almost anything with each other. It might not be the exact moment that something happens but I think some of what he likes is probably with a lot of people would say: "Well stick it up you" but at the same time I'm more bendable for people than he would be. I see a lot of grey and he would be a black and white person. But that's what I like about him. When I feel I give people too much and be a bit too flexible or too forgiving he kind of goes-he's able to function with a lot less people than I am. He doesn't care too much about a whole lot of social interaction, needs very few people, which I like as well.

For Mary socio-sexual compatibility was highlighted by the complementary nature of her and her partner's personality and character traits. In doing so, socio-sexual compatibility facilitated a communicative process between them which exemplified their acceptance and appreciation of one another. Leah's sexual experiences with her boyfriend highlight socio-sexual compatibility as a mixture of her boyfriend's awareness, receptiveness and attentiveness to her socio-sexual needs.

Leah: Yeah, my boyfriend helps me [during sexual intercourse] if I get in a certain position and I go "Left hip, left hip, left hip," he knows to do something—he's got a fairly good sense of it now. So he'll say "I don't want to hurt you more!” I've only slept with him. I've done other things with other people but I just did not, I could not fathom that kind of physical intimacy when it might have just been a whole lot of different things other people wanted from me. I'm not quite sure what went into it but I didn't hesitate with him. And I think that's important too.

For Leah, socio-sexual compatibility was characterized by her partner's awareness, receptiveness and attentiveness to her physical needs. In doing so she felt as though physical intimacy with her boyfriend did not drain her through mental and physical exertion. Similarly John's experience with his former carer indicated that upon further reflection the sexual experience he shared with her was facilitated by emotional, mental, social and physical compatibility.

John: I mean now that I think about it Emily [not real name] and I had quite unwittingly become closer than carer and caree should have been. We were both very comfortable with each other and I guess part of that was because we were happy to talk to each other. I mean we must have had, you know a mutual interest. And I guess we had to a certain extent similar senses of humour. I mean there must have been trigger points even though neither of us really thought about it deliberately. We were very very comfortable with each other. And again, home care is a very tactile, touching profession, well I mean it has to be because of the care involved and I mean probably, she and I, although we probably weren't aware of it or did it deliberately we probably encouraged each other to become, well you know, just sort of open and tactile with each other where with other people I probably hadn't or wouldn't have.

In summary, the participants of this study appeared to feel that, in addition to peer acceptance of impairment and disability, feeling worthy of sexual experiences with others, the importance of communication and the role of intimacy and finding someone who was socially and sexually compatible helped to facilitate positive perceptions of their sexual experiences with others.

\section{Limitations}

This study had some limitations; 1) cultural homogeneity, 2) restrictions of qualitative methodology, and 3) constraints of script theory. First, the cultural frame was homogenous. Namely all the participants in this study were Caucasian, from developed nations, had completed post-secondary education and were within the spectrum of middle class socio-economic status. As such, the participants of this study may only represent a range and depth of socio-sexual development experienced by members of privileged ethnic groups and resourced nations. Limited cultural and linguistic diversity (CALD) (Rao, Warburton \& Bartlett, 2006) may have skewed the findings. For instance, CALD within the present study may have made intersecting experiences of oppression 
more salient or it may have been identified as a sub-schema under public or interactional sexual schema. However, without information from CALD respondents the findings may lack cross-cultural utility. In addition, socioeconomic status may have a significant effect on socio-sexual agency and independence for people with Cerebral Palsy. For instance, people with significant disabilities with financial means may have more flexibility or autonomy in the provision of their health care than those who do not (Schillmeier, 2007). Financial means may also support independent living, social opportunities and sexual development. Research which includes a more culturally, ethnically and financially diverse sample is needed in order to determine whether these points of diversify would have an impact on the findings of this study.

Second, the qualitative methodology used within this study allowed for rich descriptive and contextual information. Interpretive inquiry allows for some data contours to be emphasized more than others (Mayoux, 2006). For instance, the data collected is mediated by the investigator's ability to ask questions or probe answers which allowed respondent's to comprehensively articulate their concepts, conceptualizations and conceptions of sexuality with disability. In doing so respondents may have found it easier to express some or certain sexual schema and not others due to their abstract nature or convolutions within the questions. While the in-depth interview technique used within the study provided insight about the meanings people with Cerebral Palsy give to their sexual lives a more ethnographic approach may have been beneficial. For example, if the investigator had spent more time with the participants in a non-interview environment they may have gained addition access to contextual information which may have been useful in the interpretation of participant data (Shuttleworth, 2000). This addition of contextual information may have alleviated the issue of convoluted questions or abstract articulations of sexual phenomena. Research which explores constructions of sexuality with Cerebral Palsy using different qualitative techniques (i.e., focus groups, case studies and observations) would further clarify the findings of this study.

Finally, sexual script theory was the theoretical basis for this research. Sexual script theory however, delineates sexual influences into public, interactional and private sexual schema. The results from the present inquiry indicate that public, interactional and private sexual schema are interdependent in their effect on constructions of sexuality with Cerebral Palsy. Interdependence of theoretical constructs introduces interdeterminancy (Dworkin 1985). This is to say that sexuality as constructed by people with Cerebral Palsy cannot be dissected and explained within the confines of public, interactional or private sexual schema. The findings of this study emphasize that people with Cerebral Palsy are agents in the construction of their sexuality. Bandura's social cognitive theory $(1986,1997,2006)$, which highlights people as social agents, may therefore be a better theory to apply to constructions of sexuality with Cerebral Palsy. Research which employs Bandura's social cognitive theory and constructions of sexual with disability would be beneficial to further understanding agency and sexuality with disability.

\section{Conclusion}

This study sought to explore, understand and to develop existing knowledge and theory on how people with Cerebral Palsy constructed their sexuality. Bringing to the fore discussions on both sexual agency and being, this study found that constructions of sexuality with Cerebral Palsy are primarily influenced by interactional sexual schema. It also highlights the role of sexual participation through sexual exploration. This thesis has demonstrated - through the utilization of sexual script theory - the complexity of individual constructions of sexuality with Cerebral Palsy.

Although the findings from this study can be used to inform further estimations about individual sexuality, they initiate important discussions around the theoretical and practical implications sexual agency with disability. Primarily, sexual theory needs to be more cognizant of sexual agency as primary in the construction of sexuality with significant disability. In addition, healthcare providers and people with Cerebral Palsy must work as partners in sexual health in order to support positive and agentic constructions of sexuality with significant disability.

Summarily, this study emphasizes that people with Cerebral Palsy are intelligent and cognizant participants in the construction of their sexuality. Their understandings, articulations and descriptions of their sexuality speak to their awareness and interest in their sexuality and issues related to it. In this way, people with Cerebral Palsy are sexual beings and agents who empower themselves. This is achieved through their creation of and participation in innovative pathways to participation. In doing so, people with Cerebral Palsy actively seek out social and sexual opportunities which suit and fulfill their social and sexual desires. People with Cerebral Palsy make it clear that (their) sexuality is there/theirs for the taking. 


\section{References}

Bandura, A. (2006). Guide for constructing self-efficacy scales. In F. Pajares, \& T. C. Urdan, Self-efficacy beliefs of adolescents (pp. 307-338). Charlotte: Information Age Publishing.

Bandura, A. (1997). Self-efficacy: The exercise of control. New York: 1997.

Bandura, A. (1986). Social foundations of thought and action: A social cognitive theory. Englewood Cliffs: Prentice-Hall.

Barber, K., Berger, A., Ricci, C., Sperling, A., \& Yerxa, R. (Producers). (2002). Pumpkin [Motion Picture]. United States.

Blakar, R. M., \& Nafstad, H. E. (2006). Towards a definition of communication encompassing ethical dimensions. In R. Keeble, Communication Ethics Today (pp. 177-186). Leicester: Troubador Publishing Ltd.

Clarke, V., Kitzinger, C., \& Potter, J. (2004). Kids are just cruel anyway: Lesbian and gay parents talk about homophobic bullying. British Journal of Social Psychology, 43(4), 531-550.

Dune, T. M., \& Shuttleworth, R. P. (2009). "It's just supposed to happen”: The myth of sexual spontaneity and the sexually marginalized. Sexuality and Disability, 27(2), 97-108.

Dworkin, R. A. (1985). "Why Should Liberals Care about Equality" in A Matter of Principle. Cambridge: Harvard University Press.

Earle, S. (2001). Disability, facilitated sex and the role of the nurse. Journal of Advanced Nursing, 36(3), 433-440.

Esmail, S., Darry, K., Walter, A., \& Knupp, H. (2010). Attitudes and perceptions towards disability and sexuality. Disability and Rehabilitation, 32(14), 1148-1155.

Esmail, S., Esmail, Y., \& Munro, B. (2001). Sexuality and disability: The role of health care professionals in providing options and alternatives for couples. Sexuality and Disability, 19(4), 267-287.

Falkman, K. W., Sandberg, A. D., \& Hjelmquist, E. (2005). Theory of mind in children with severe speech and physical impairment (SSPI): A longitudinal study. International Journal of Disability Development and Education, 52(2), 139-157.

Gould, J. (2009). There is more to communication than tongue placement and 'show and tell': Discussing communication from a speech pathology perspective. Australian Journal of Linguistics, 29(1), 59-73.

Guildin, A. (2000). Self-claiming sexuality: Mobility impaired people and American culture. Sexuality and Disability, 18(4), 233-238.

Howland, C. A., \& Rintala, D. H. (2001). Dating behaviours of women with physical disabilities. Sexuality and Disability, 19(1), 41-70.

Jemtå, L., Fugl-Meyer, K. S., \& Öberg, K. (2008). On intimacy, sexual activities and exposure to sexual abuse among children and adolescents with mobility impairment. Acta Pediatrica, 97(5), 641-646.

Kralik, D., \& Bostock, N. (2008). Sexuality in chronic illness and disability. In E. Chang, \& A. Johnson, Chronic Illness and Disability: Principles for Nursing Care (pp. 77-90). Sydney: Elsevier Australia.

Lawlor, K., Mihaylov, S., Welsh, B., Jarvis, S., \& Colver, A. (2006). A qualitative study of the physical, social and attitudinal environments influencing the participation of children with cerebral palsy in northeast England. Developmental Neurorehabilitation, 9(3), 219-228.

L'Engle, K. L., Brown, J. D., \& Kenneavy, K. (2006). The mass media are an important context for adolescents'. Journal of Adolescent Health, 38, 186-192.

Mayoux, L. (2006). Quantitative, qualitative or participatory? which method, for what and when. In V. Desai, \& R. B. Potter, Doing development research (pp. 113-129). London: Sage.

McCabe, M. P., Cummins, R. A., \& Deeks, A. A. (2000). Sexuality and quality of life among people with physical disability. Sexuality and Disability, 18(2), 115-123.

McCormack, J., McLeod, S., McAllister, L., \& Harrision, L. (2010). My speech problem, your listening problem, and my Frustration: The experience of living with childhood speech impairment. Language, Speech, and Hearing Services in Schools, 41(4), 379-392.

Milligan, M. S., \& Neufeldt, A. H. (2001). The myth of asexuality: A survey of social and empirical evidence. 
Sexuality and Disability, 19(2), 91-109.

Neemann, J., Hubbard, J., \& Masten, A. S. (1995). The changing importance of romantic relationship involvement to competence from late childhood to late adolescence. Development and Psychopathology, 7(4), 727-750.

Overstreet, L. C. (2008). Splitting sexuality and disability: A content analysis and case study of internet pornography featuring a female wheelchair user. Sociology Theses. Paper 22.

Paek, H. J. (2009). Differential effects of different Peers: Further evidence of the peer proximity thesis in perceived peer influence on college students' smoking. Journal of Communication, 59(3), 434-455.

Papile, C. (2009). Factors that help and hinder the relationship between veterans and their partners: The partners' perspective. Kingston: Queen's University.

Phillips, S. (2008). In love and college: A practical guide to practical relationships. Lulu.com.

Potard, C., Courtois, R., \& Rusch, E. (2008). The influence of peers on risky sexual behaviour during adolescence. The European Journal of Contraception and Reproductive Health Care, 13(3), 264-270.

Rao, D. V., Warburton, J., \& Bartlett, H. (2006). Health and social needs of older Australians from culturally and linguistically diverse backgrounds: issues and implications. Australasian Journal on Ageing, 25(4), 174-179.

Rurangirwaa, J., Van Naarden Braun, K., Schendel, D., \& Yeargin-Allsopp, M. (2006). Healthy behaviours and lifestyles in young adults with a history of developmental disabilities. Research in Developmental Disabilities, 27(4), 381-399.

Schillmeier, M. (2007). Dis/abling spaces of calculation: blindness and money in everyday life. Environment and Planning D., 25, 594-609.

Shuttleworth, R. P. (2000). The Search for Sexual Intimacy for Men with Cerebral Palsy. Sexuality and Disability, 18(4), 263-282.

Simon, W., \& Gagnon, J. H. (1986). Sexual scripts: Permanence and change. Archives of Sexual Behaviours, 15(2), 97-120.

Simon, W., \& Gagnon, J. H. (1987). A sexual scripts approach. In J. H. Geer, \& W. T. O'Donohue, Theories of human sexuality (pp. 363-383). London: Plenum Press.

Simon, W., \& Gagnon, J. H. (2003). Sexual scripts: Origins, influences and changes. Qualitative Sociology, 26(4), 491-497.

Sullivan, H. S. (1953). The interpersonal theory of psychiatry. New York: Norton.

Taleporos, G., \& McCabe, M. (2002). The impact of sexual esteem, body esteem, and sexual satisfaction on psychological well-being in people with physical disability. Sexuality and Disabiltiy, 20, 177-183.

Taleporos, G., \& McCabe, M. (2005). The relationship between the severity and duration of physical disability and body esteem. Psychology and Health, 20(5), 637-650.

Wazakili, M., Mpofu, R., \& Devlieger, P. (2009). Should issues of sexuality and HIV and AIDS be a rehabilitation concern? The voices of young South Africans with physical disabilities. Disability and Rehabilitation, 31(1), 32-41.

Wiegerink, D. J., Roebroeck, M. E., Donkervoort, M., Stam, H. J., \& Peggy, T. (2006). Social and sexual relationships of adolescents and young adults with cerebral palsy: A review. Clinical Rehabilitation, 20, 1023-1031.

Wu, Q., \& Mok, B. (2006). Mental health and social support: A pioneering study on the physically disabled in southern China. International Journal of Social Welfare, 16(1), 41-54.

Xenakis, N., \& Goldberg, J. (2010). The Young Women's Program: A health and wellness model to empower adolescents with physical disabilities. Disability and Health Journal, 3(2), 125-129.

\section{(cc) $\overline{E Y}$}

This work is licensed under a Creative Commons Attribution 3.0 License. 